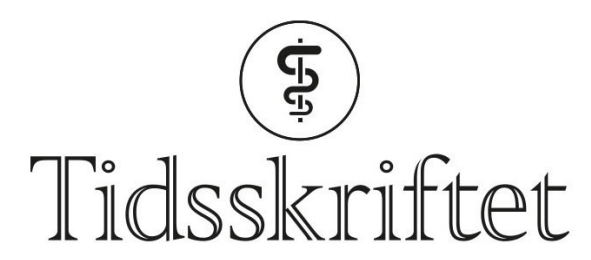

DEN NORSKE LEGEFORENING

\title{
Forside nr. 11/2020
}

FORSIDE

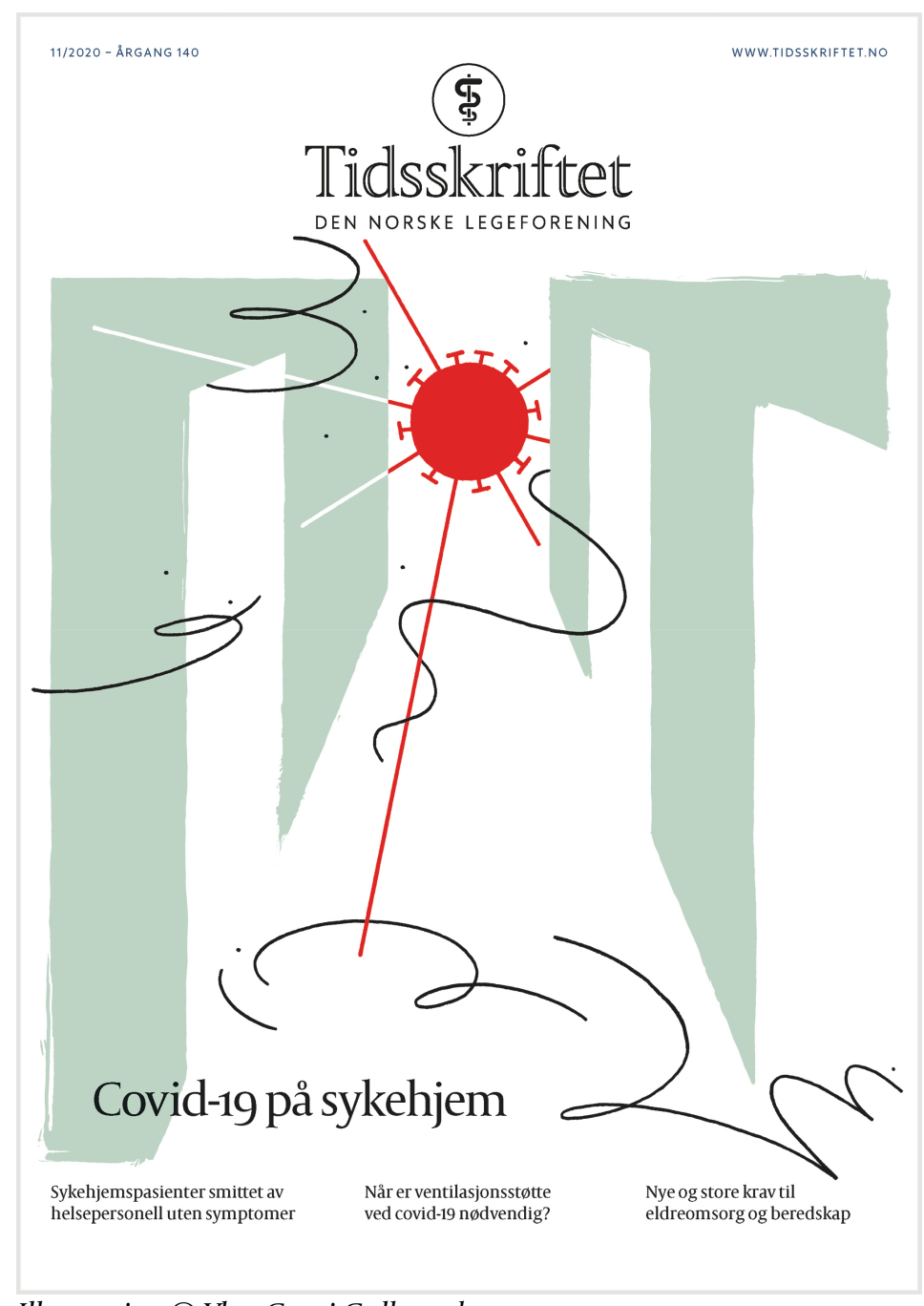

Illustrasjon (C Ylva Greni Gulbrandsen

Noen av de tristeste historiene fra begynnelsen av koronapandemien kom fra sykehjemmene, dystre rapporter fra utlandet om hele pleiehjem som var forlatt. Sykehjemmene var hverken bygd eller bemannet for å kunne isolere pasienter, og det var ikke nok smittevernutstyr. Her hjemme handlet alt om å beskytte samfunnets kanskje mest sårbare. Besøk ble først forbudt, deretter strengt regulert. Men beskyttelsen mot smitte hadde også en pris. For dem med få måneder igjen å leve er ukesvis uten et kjent ansikt eller en klem kanskje for lenge. Og for dem som sliter med å holde styr på tid, sted og mennesker, må det være skremmende når ansiktene er gjemt bak masker, hetter og briller. I dette nummeret har vi en originalartikkel om utbrudd av covid-19 ved tre sykehjem i Bergen. 
Forsiden er tegnet av Ylva Greni Gulbrandsen. Flere av hennes arbeider finner du her: https://ylvagreni.com/

Publisert: 17. august 2020. Tidsskr Nor Legeforen. DOI: 10.4045/tidsskr.20.11.02

(C) Tidsskrift for Den norske legeforening 2020. Lastet ned fra tidsskriftet.no 